\title{
O НЕКОТОРЫХ
}

АРХАИЧЕСКИХ ЧЕРТАХ

В ВОСПРИЯТИИ

КАТЕГОРИЙ «СВЯТОСТЬ»

И «ГРЕХ В НАРОДНОМ

ПРАВОСЛАВИИ

(ПОЧИТАНИЕ

ЗЕМЛИ-МАТЕРИ

И ЕГО МЕСТО В РУССКОЙ

РЕЛИГИОЗНОСТИ)

\author{
Протоиерей Олег Корытко \\ кандидат богословия \\ доцент кафедры богословия Московской духовной академии \\ доцент кафедры церковной истории \\ Сретенской духовной академии \\ 141300, Московская область, Сергиев Посад, \\ Троице-Сергиева лавра, Академия \\ priest@list.ru \\ ORCID: https://orcid.org/0000-0003-0812-4350
}

Для цитирования: Корытко О., прот. О некоторых архаических чертах в восприятии категорий «святость» и «грех» в народном православии (почитание Земли-Матери и его место в русской религиозности) // Богословский вестник. 2021. № 4 (43).C. 286-302. DOI: 10.31802/GB.2021.43.4.017 
представлениями о сакральности земли и с культом плодородия. После принятия крещения в картине мира восточных славян вместе с христианскими ценностями продолжали существовать и некоторые архаические элементы. Многие из них органично интегрировались в православную народную традицию и стали значимой частью религиозного сознания. Однако народные представления о грехе не всегда полностью совпадали с церковными этическими установлениями и каноническими нормами. Народная вера содержит ряд запретов и ограничений, прежде всего бытового и обрядового характера, которые не только не могут быть напрямую выведены из текста Священного Писания или святоотеческого наследия, но едва ли вообще могут быть сопряжены с православным учением. Такое расхождение во многом обусловлено специфическими особенностями восприятия святости, восходящего к дохристианской эпохе и связанного с архаическими представлениями о святости как об избытке жизненных сил, носительницей которых является, в частности, земля - подательница благ и кормилица человека. Следы этого почитания, прочно укоренённого в культурной памяти народа, имеются не только в произведениях фольклорного жанра, но и в бытовых практиках и даже религиозных обычаях, многие из которых актуальны и по сей день. Рудиментами подобного благоговейного отношения к земле, свойственного не только нашим предкам, но и современникам, следует признать, среди прочего, бытование специфических запретов на сельскохозяйственные работы в определённые православные праздники, а также обыкновение собирать лекарственные растения в особые дни церковного календаря.

Ключевые слова: народное православие, русская религиозность, святость, грех, земля-мать, культ плодородия, архаические представления.

\title{
About some Archaic Features in the Perception of the Categories "Holiness" and "Sin" in Folk Orthodoxy: Veneration of the Mother Earth and its Place in Russian Religiosity
}

\author{
Archpriest Oleg Korytko \\ $\mathrm{PhD}$ in Theology \\ Associate Professor at the Department of Theology \\ at the Moscow Theological Academy \\ Associate Professor at the Department of Church History \\ at the Sretensky Theological Academy \\ Holy Trinity-St. Sergius Lavra, 141300 Sergiev Posad, Russia \\ priest@list.ru \\ ORCID: https://orcid.org/0000-0003-0812-4350
}

For citation: Korytko, Oleg, archpriest. "About some Archaic Features in the Perception of the Categories 'Holiness' and 'Sin' in Folk Orthodoxy: Veneration of the Mother Earth and its Place in Russian Religiosity”. Theological Herald, no. 4 (43), 2021, pp. 286-302 (in Russian). DOI: 10.31802/GB.2021.43.4.017 
Abstract. The article examines the peculiarities of the popular perception of such fundamental worldview categories as «holiness» and «sin», which are associated with archaic ideas about the sacredness of the earth and the worship of fertility. After the embracing of Baptism, some archaic elements continued to coexist with Christian values in the worldview of the Eastern Slavs. Plenty of them have been organically integrated into the Orthodox folk tradition and have become an important part of religious consciousness. However, the popular ideas about sin did not always fully match the Church's ethical guidelines and canonical norms. The popular faith contains a number of prohibitions and restrictions, primarily of a domestic and ritual nature which neither can be directly derived from the text of Holy Scripture or the patristic heritage nor can much be associated with Orthodox doctrine at all. This discrepancy is largely due to the specific features of the perception of holiness, dating back to the pre-Christian era and associated with archaic ideas about holiness as an excess of vitality, the holder of which is, in particular, the Earth as the giver of assets and the provider of man. Traces of this veneration, firmly rooted in the cultural memory of the people, are found not only in the works of the folklore genre but also in domestic practices and even religious customs, many of which are relevant to this day. Inter alia, the existence of specific prohibitions on agricultural work on certain Orthodox holidays, as well as the habit of collecting medicinal herbs on special days of the church calendar, should be recognized as rudiments of such a reverent attitude to the earth, characteristic not only of our ancestors but also of our contemporaries.

Keywords: folk Orthodoxy, Russian religiosity, holiness, sin, Mother-Earth, fertility cult, archaic ideas. 


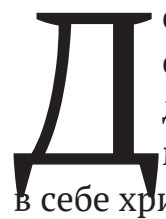
есять столетий минуло с крещения нашего народа в днепровских водах. Века христианизации и просветительских трудов, проходивших не всегда гладко и безболезненно, сформировали особый тип русской религиозности, соединившей истианские черты с архаическими представлениями ещё дохристианской эпохи.

Сей удивительный сплав очень ярко проявился в народной морали, которая, по верному замечанию В. М. Живова, «сохраняла определённую автономию по отношению к церковной доктрине» ${ }^{1}$. Одной из важнейших категорий духовной жизни человека является понятие греха. Анализ представлений о грехе, очевидным образом противостоящем святости, помогает обнаружить такие мировоззренческие оппозиции, как сакральное vs профанное, дозволенное vs запретное, выявить ценности, которые определяют парадигму поведения человека и его образ мышления.

Авторы этнолингвистического словаря традиционной духовной культуры «Славянские древности» ${ }^{2}$ вслед за Г. П. Федотовым ${ }^{3}$, изучавшим феномен народной веры на примере анализа духовных стихов, выделяют в качестве главной особенности народной этики категорию грехов против нравственного закона Земли-Матери. Выбранные в качестве материала для исследования духовные стихи - жанр религиозной поэзии, чрезвычайно популярный до революции, - дают благодатную почву для изучающего народное православие. Но сразу возникает резонный вопрос: какое отношение могут иметь сделанные в первой половине XX в. наблюдения (свой труд про духовные стихи Г. П. Федотов издал в 1935 г.) к современному народному православию? Насколько применимы сделанные исследователями выводы к русской народной вере сегодня?

Разумеется, было бы ошибкой утверждать абсолютную тождественность народного православия столетней давности и народного православия в его нынешнем виде. Разрыв с христианской духовной традицией, курс на который взяли пришедшие к власти большевики, на многие десятилетия вверг наш народ в культурно-историческое

1 Живов В.М. Грьховодник. К истории слова и понятия // Очерки исторической семантики русского языка раннего Нового времени / под ред. В. М. Живова. М., 2009. С. 426.

2 Толстой Н. И. Грех // Славянские древности. Этнолингвистический словарь: В 5 т. / под общ. ред. Н. И. Толстого. Т. 1: А-Г. М., 1995. С. 544-546.

3 Федотов Г.П. Стихи духовные (Русская народная вера по духовным стихам) / вступ. ст. Н. И. Толстого. М., 1991. 
беспамятство и даёт о себе знать и поныне. Однако, несмотря на это, сохраняется в религиозности русского человека нечто трудноуловимое, что не преодолено до конца многовековой и терпеливой просветительской деятельностью Церкви и уж тем более не выжжено калёным железом атеистической пропаганды, затуманившей, но не истребившей религиозное чувство народа. С открытием возможностей беспрепятственно изучать собственную культуру и историю, с погружением в мир национальной традиции что-то глубинное, родное всколыхнулось в душе русского человека.

Вне всякого сомнения, исторические перемены необратимы, и в реку истории не войти дважды. Но одно совершенно точно: «второе Крещение Руси», как ещё иногда называют постсоветскую эпоху, сопровождается теми же миссионерскими вызовами и задачами, с которыми сталкивались наши далёкие предшественники на ниве духовного просвещения. Сознание наших современником сложно назвать полностью христианским, в чём приходится убеждаться, в том числе, и на примере собственного скромного пастырского опыта.

Возвращаясь к теме греха, особенностей его восприятия современным русским человеком - носителем православной духовной традиции, а также интерпретации выводов о народной морали, сделанных исследователями народной веры, необходимо ввести несколько предварительных поясняющих замечаний об архаическом понимании святости (в силу её очевидной противоположности греху) и месте ЗемлиМатери в славянских религиозных представлениях, чтобы сопоставить их с современными данными и оценить справедливость проведения религиоведческих параллелей.

\section{Святость как изобилие жизненных сил}

Представления о сакральности выражались в языке древних славян словами с корнем *svęt-. Выдающийся отечественный филолог В. Н. Топоров, подробно изучавший феномен древнерусской святости и посвятивший этой теме внушительную двухтомную монографию4, пишет о том, что праславянское *svęt этимологически восходит к индоевропейскому корню "k'uen-to-. Для понимания специфики древнеславянского восприятия святости В. Н. Топоров предлагает взглянуть на праславянское

4 Топоров В.Н. Святость и святые в русской духовной культуре: В 2 т. Т. 1. Первый век христианства на Руси. М., 1995. 
*svęt- в общеиндоевропейском контексте ${ }^{5,6}$. Анализируя данные индоиранских (в частности, древнеиндийского, авестийского, хотаносакского, скифского, тохарских А и В), германских (в частности, готского и древнеанглийского), а также балтийских языков, Топоров реконструирует индоевропейские истоки концепции святости, стремится определить языковую мотивировку, вскрывающую значение этой важнейшей для архаической картины мира категории.

Индоевропейское значение *k'uen-to-, унаследованное, в том числе, и праславянским *svęt-, неразрывно связано с представлениями о жизненной силе, росте, плодородии и выражает идею возрастания, изобилия и процветания. Особенно ярко эти значения проявляются, в частности, в индоиранских языках. Так, например, в текстах Ригведы - одного из древнейших памятников ведийской литературы - зафиксированы многочисленные формы, производные от гла-

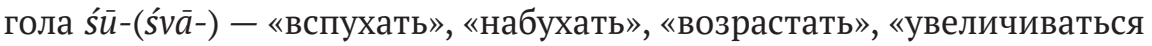
в размере» и т.п. Есть среди них и форма śvāntá-, которая точно соответствует индо.-европ. *k'uen-to- и праслав. *svęt-. Обращают на себя внимание контексты употребления указанной формы: одни из них напрямую связаны с огнём (очевидно, полученным специальным образом и потому имеющим сакральное значение), а другие - с идеей процветания и возрастания в силе. Мифологические образы святости огня будут впоследствии характерны и для славянской традиции.

Схожую «огненную» тематику встречаем и в авестийском. Но при этом святостью (spənta- - «святой») наделяется не только огонь, но и «разные формы психо-ментальной деятельности и её результатов» ${ }^{7}$. Речь, в частности, идёт о «святой мудрости», носителями которой, в соответствии с древнеиранскими (зороастрийскими) представлениями, являются Небо («верхняя мудрость», разум) и Земля («нижняя мудрость», плодоносящее начало). Очевидно, что соединение этих видов мудрости обеспечивает непрерывное продолжение жизни и вечное бытие мироздания. Топоров указывает на особую внутреннюю связь идеи бессмертия и святости в текстах Авесты и подчёркивает, что подобное «понимание святости как формы бессмертия, обеспечиваемого

5 Топоров В.Н. Об одном архаичном индоевропейском элементе в древнерусской духовной культуре - * svęt // Языки культуры и проблемы переводимости. М., 1987. С. 184-252. Топоров В.Н. Из славянской языческой терминологии: индоевропейские истоки и тенденции развития // Этимология. 1986-1987 / под ред. Ж. Ж. Варбот, Л. А. Гиндина, Г. А. Климова, В. А. Меркуловой, В. Н. Топорова, О. Н. Трубачёва. М., 1989. С. 3-50. 
целостностью и возрастанием жизненной силы, также близко тому, что реконструируется для славянской духовной традиции и находит отражение в представлениях о святости в ряде памятников древнерусской житийной литературы» ${ }^{8}$.

Но самое интересное наблюдение исследователя относится к тому, что предлагают данные хотаносакского (хотанского) языка, принадлежащего к восточно-иранской группе. В этом языке мотив мудрой МатериЗемли раскрывается наиболее ярко и выразительно. Для названия земли в нём могут использоваться два слова, несущие в своих частях элемент «святости»: ysamaśśandā̄- — «святая земля» и просто śśandaā- — «святой». Факт равноправного употребления этих лексем и, более того, сама возможность атрибутировать землю по принципу свойственной ей святости, даже без дополнительного указания на объект, даёт все основания утверждать крепкую связь между данными понятиями.

Рассмотрение праслав. *svęt- на этом фоне позволяет предположить наличие подобных смыслов в понимании земли как носительницы святости и в картине мира древних славян, особенно с учётом установленных лингвистами тесных славяно-иранских схождений в области духовной культуры 9 .

Впрочем, древнеславянская семантика святости как изобилия сил, плодородия и «жизненности» может быть подтверждена не только автоматическим проецированием данных индоевропейских языков на праславянскую реальность. Подтверждается она и эмпирически: в особо трепетном, сохраняющемся по сей день отношении русского народа к земле. Безусловно, идеи плодовитости и биологической силы занимают существенное место в аксиологической системе любого народа, но в случае со славянами они приобретают особое звучание и значение, поскольку «сопряжены прежде всего с земледельческим характером их осёдлой культуры» ${ }^{10}$.

8 Топоров В.Н. Из славянской языческой терминологии: индоевропейские истоки и тенденции развития // Этимология. 1986-1987 / под ред. Ж. Ж. Варбот, Л. А. Гиндина, Г. А. Климова, В. А. Меркуловой, В. Н. Топорова, О. Н. Трубачёва. М., 1989. С. 13.

9 Подробнее об этом см.: Зализняк А. А. Проблемы славяно-иранских языковых отношений древнейшего периода // Вопросы славянского языкознания. 1962. Вып. 6. С. 28-47; Трубачёв О.Н. Из славяно-иранских лексических отношений // Этимология. 1965. Материалы и исследования по индоевропейским и другим языкам. М., 1967. С. 3-81; Jakobson R. Slavic Mythology // Funk and Wagnall's Standard Dictionary of Folklore. Mythology and Legend. 1972. P. 1025-1028.

10 Журавлёв А.Ф. Древнеславянская фундаментальная аксиология в зеркале праславянской лексики // Он же. Эволюции смыслов. М., 2016. С. 72. 
Выражения «святость материнства», «святая земля» очень органично звучат для русского уха. Где как не в материнстве выражается полнота жизненных сил человека? Что как не земля является воплощением этих жизнедающих сил в природе? Показательным представляется в связи с этим и замечание О. Н. Трубачёва, сделанное им в отношении употребительной русской пословицы: свято место пусто не бывает, изначальный смысл которой, по мнению учёного, дешифруется из наличия в ней явной смысловой оппозиции святой пустой: изобильное место не бывает пустым. Пустое и бесплодное противостоит, таким образом, плодоносящему и рождающему новую жизнь началу, которое в силу именно этих своих качеств свято и благословенно. Эта пословица, по убеждению Трубачёва, «говорит сама за себя и дышит архаикой» ${ }^{11}$.

С принятием крещения наш народ включил в сложный комплекс христианских представлений и особое почитание Матери-Земли, ставшее отголоском архаического культа плодородия, понимаемого как выражение жизненных сил человека, природы и всего мироздания.

\section{Народное почитание Земли-Матери: традиции, обряды, запреты}

Как уже было отмечено выше, представления о святости земли уходят корнями в индоевропейскую древность. Для славян, наследовавших подобные воззрения, образ земли также был неразрывно связан с рождающим материнским началом, мудростью и жизнью.

Все тот же В. Н. Топоров отмечал, что для индоевропейцев Земля (имя собственное для образа земли), «несомненно, обладает высшим религиозно-аксиологическим статусом, подтверждаемым и характером её культа» ${ }^{12}$. Этот статус даже можно назвать божественным, о чём говорит упоминание Земли среди языческих божеств в одном из самых популярных древнерусских апокрифов «Хождение Богородицы по мукам» ${ }^{13}$.

11 Трубачёв О.Н. Мысли о дохристианской религии славян в свете славянского языкознания // Он же. Труды по этимологии: слово, история, культура. М., 2005. Т. 2. С. 428.

12 Топоров В. Н. К реконструкции балто-славянского мифологического образа Земли-Матери *Zemia \& *Mātē (*Mati) // Балто-славянские исследования 1998-1999. XIV. Сборник научных трудов. М., 2000. С. 245. 
Конечно, сегодня едва ли найдётся человек, который искренне верит в божественность земли, если только он не сознательно исповедует язычество и не отвергает всякую связь с христианской Церковью. Между тем и поныне сохраняются в нашем народе некоторые примечательные обычаи, которые свидетельствуют о том, что почитание земли всё ещё живо, хотя имеет во многом интуитивный характер и трудно объяснимо самими носителями этих культурных традиций. Люди воспроизводят модели поведения, которые восприняли от родителей, бабушек или дедушек, но не всегда могут дать рациональное обоснование своих действий, ссылаясь лишь на мудрости предков.

Замечательным примером, иллюстрирующим живость и актуальность народных представлений о святости земли, является и по сей день сохраняющийся обычай «не беспокоить» землю в праздник Благовещения. Данный праздник всегда особо почитался на Руси, и это не случайно. Будучи напрямую связан с зачинанием земной жизни Иисуса Христа, являясь «главизной нашего спасения», как поётся в церковном тропаре, он занимал важнейшее место в народном религиозном сознании, осмыслявшем его как начало нового природного и сельскохозяйственного цикла и ассоциировавшем его с обновлением жизненных сил земли. Именно поэтому в этот день строго запрещались любые аграрные и хозяйственные работы, затрагивавшие или «тревожащие» землю: не только копание или вспашка почвы, но и забивание кольев и установка заборов. По народным представлениям, «до Благовещения земля “спит” или “беременна”, а в день Благовещения она “раскрывается” и выпускает на свет растения, змей, насекомых» ${ }^{14}$. Как сообщают авторы этнографической энциклопедии «Русский народ», по крестьянским представлениям, «в день Благовещения Сам Бог благословляет землю, открывает её на сеяние. Отсюда возник обычай накануне этого праздника или на самый праздник освящать просфоры или семена: те и другие потом хранились крестьянами до первых весенних посевов как знак видимого благословения Божия для хорошего роста и плодородия своих нив» ${ }^{15}$.

В 1992 г. от жительницы г. Скопина Рязанской области О. Ф. Коробейниковой автору доводилось слышать благочестивое сказание о том, как некая мать предупреждала свою дочь воздерживаться в праздник Благовещения от любых, даже самых простых работ,

14 Толстой Н. И. Грех // Славянские древности. Этнолингвистический словарь. Т. 1. С. 545.

15 Русский народ (Вера и обычаи. Работа и быт. Будни и праздники). Этнографическая энциклопедия в 2 т. / гл. ред., сост. О. А. Платонов. М., 2013. Т. 1: А-Н. С. 94. 
ссылаясь на народную поговорку, что в сей день «птица гнезда не вьёт, девица косы не плетёт». В ответ молодая девушка показала на горлицу, занимавшуюся как раз в тот момент сооружением гнезда на соседнем дереве. Тотчас, будто в назидание людям, пернатая нарушительница ритуальных норм была растерзана появившимся внезапно соколом.

Работа в церковные праздники вообще считалась тяжёлым грехом в народе, поскольку может привести «к нарушению природного равновесия и установленного миропорядка» ${ }^{16}$. За труд в эти дни человека и, даже шире, всю общину может постигнуть серьёзное наказание в виде неурожая, болезней скота или природных бедствий.

Сопоставимый по значимости запрет тревожить землю относится к великому празднику Пятидесятницы (Святой Троицы) и следующему за ним Духову дню. Вообще праздники так называемого Троицкого цикла, включающие в себя Вознесение, Семик, Троицу и Духов день, занимают особое место в народном земледельческом календаре и отмечают конец весны и начало лета. В эти дни строго воспрещается всякая работа на земле, причём запрет распространялся не только на сельскохозяйственную обработку, но и вообще на всякое физическое воздействие на неё (например, ковыряние палкой или бросание ножика). Нарушение запрета, совершение греха против земли, по народному убеждению, способно привести к неурожаю или болезням растений. В популярных сегодня интернет-рубриках «Что можно и чего нельзя делать на N-ский церковный праздник?» часто приводится суждение о том, что «на Троицу и в Духов день нельзя касаться земли» ${ }^{17}$, работать на огороде и в саду, выливать помои на землю. Такие запреты, как отмечают авторы «Славянских древностей», связаны с восточнославянскими представлениями о том, что в Духов день земля - именинница ${ }^{18}$.

Облекаясь Божественной силой, которая разливается в эти дни по всей вселенной, земля таким образом освящается. С данным представлением связан также бытующий и поныне обычай собирать именно в праздник Святой Троицы и Духов день лекарственные растения,

16 «Народная Библия»: восточнославянские этиологические легенды / сост. и коммент. О. В. Беловой; отв. ред. В. Я. Петрухин. М., 2004. С. 95.

17 См., например, советы и рекомендации, размещённые на следующих популярных Интернет-ресурсах: URL: https://www.kp.ru/putevoditel/kalendar-prazdnikov/dukhov-den/ primety-na-dukhov-den/; URL: https://pronedra.ru/v21-chto-mozhno-i-nelzya-delat-17-iyunya-v-duxov-den-389922.html; URL: https://ftimes.ru/389532-kakie-zaprety-sushhestvovalina-duhov-den-21-iyunya-i-pochemu-lyudi-boyalis-ih-narushat.html и др.

18 Агапкина Т. А. Духов день // Славянские древности. Этнолингвистический словарь / под общ. ред. Н. И. Толстого. М., 1999. Т. 2. С. 158. 
поскольку заготовленные травы отличаются особой целительной силой. Так, например, на Русском Севере (в частности, в Вологодской области $)^{19}$ существует практика сбора в этот день листьев чёрной смородины, употребление которых в течение года, как считается, приносит облегчение страдающим от аллергии и других болезней. Схожие поверья распространяются и через многие современные средства массовой информации и Интернет, которые рекомендуют в эти дни «запастись целебными травами и цветами» ${ }^{20}$, «если же в праздник Святой Троицы женщины не успевали собрать лечебных трав, то в Духов день они исправляли это. Ведь, согласно поверьям, в этот праздник все травы не теряют своей особой силы и способны так же вылечить, как травы, собранные на Троицу» ${ }^{21}$. Особой силой, по народным верованиям, обладают сорванные ветви берёзы. Нередко их после освящения в храме ставят в домашний угол с иконами. В сельской же местности существует обычай бросания ветвей в реку или же на нивы. «Наряженная, опетая, накормленная, прославляемая в течение нескольких дней, берёзка рассматривалась как некое вместилище растительных сил. Брошенная или поставленная в хлебное поле, она должна была отдать всю свою силу, энергию роста и плодородия зеленеющей ниве, способствовать урожаю и, соответственно, благополучию людей» ${ }^{22}$. Таким образом, идея животворности Святого Духа, явленного миру, соединилась в народе с архаическими представлениями о Матери-Земле и органично связанным с ней культом растительности.

Отношение к земле как к святыне и источнику силы встречается и поныне и выражается не только в описанных выше случаях её почитания на некоторые церковные праздники, которые придают этому отношению некий «православный» характер и объяснение. Примечательным обычаем является современная практика брать в качестве святыни землю из почитаемых паломниками мест: ярким примером, в частности, служит «земелька с Богородичной Канавки» в Дивеево - тропы, где, согласно свидетельству преподобного Серафима Саровского, прошла Пресвятая Богородица.

19 Этой информацией автор обязан Е. Н. Павлушковой, уроженке этих мест.

20 URL: https://ftimes.ru/389532-kakie-zaprety-sushhestvovali-na-duhov-den-21-iyunya-ipochemu-lyudi-boyalis-ih-narushat.html

21 URL: https://pronedra.ru/v21-chto-mozhno-i-nelzya-delat-17-iyunya-v-duxov-den-389922. html

22 Некрылова А. Ф. Русский традиционный календарь на каждый день и для каждого дома. СПб., 2009. С. 709-710. 
Особого упоминания заслуживает существовавший долгое время в народе обычай, отражённый, кстати говоря, в романе Ф. М. Достоевского «Преступление и наказание», предварять церковную исповедь рассказом земле о совершённых грехах - «обряд прощания с землёю». Поскольку, как отмечал профессор С. И. Смирнов, подробно исследовавший данный феномен, «земля мыслилась как судия и как искупительница грехов» 23 , она принимает на себя людские вины, освобождает от них и, точно любящая мать, покрывает преступления человека. И хотя, по свидетельству учёного, этот обычай был распространён главным образом среди старообрядцев-беспоповцев, но и среди православных верующих он также встречался и в этом случае мыслился как обряд, дополняющий церковную исповедь: земле исповедуют только те грехи, «которых не спросит священник, грехи против самой земли» ${ }^{24}$. Сохраняется ли этот обряд в народно-православной среде сегодня, сказать довольно трудно за отсутствием прямых об этом свидетельств.

Тесно сопряжён с древним культом плодородия также ряд запретов, касающихся обращения с едой. Так, например, категорически возбраняется играть с пищей, особенно с хлебом, который является для славян воплощением рождающей силы земли и к тому же символом вечности ${ }^{25}$. Именно поэтому хлеб и зерно - постоянные участники различных народных обрядов, в которых они выполняют роль священного знака благополучия и достатка.

Можно вспомнить, к примеру, символический акт выноса каравая при встрече дорогих гостей, целующих хлеб и затем вкушающих его часть. Любопытно, кстати, что обычай встречи гостя с караваем сегодня распространён в среде духовенства, в том числе столичного. Это, в частности, касается практики встречи епархиального архиерея, которая происходит, как правило, перед литургией. Поскольку же вкусить от предлагаемого хлеба архипастырь всё равно не может, он ограничивается лишь символическим поцелуем хлеба. Ещё одной примечательной деталью данного обычая служит личность держателя каравая. Поскольку настоятель встречает архиерея у въезда на территорию храма, то сам акт преподнесения хлеба делегируется, как правило, его супруге. При свойственном архаическому сознанию функциональном отождествлении земли и женщины женщина-мать с огромным караваем

23 Смирнов С. И. Исповедь земле // БВ. 1912. Т. 4. № 11. С. 526.

24 Там же. С. 536.

25 Подробнее о культе хлеба см.: Страхов А. Б. Культ хлеба у восточных славян. Опыт этнолингвистического исследования. München, 1991. 
(образным плодом земли), встречающая почётного гостя у входа в храм, может рассматриваться, говоря языком М. Элиаде, как иерофания ${ }^{26}$, явленная в данном случае в женском модусе символическим способом в ритуальном контексте.

Можно вспомнить также и поныне распространённый свадебный обычай осыпать зерном молодожёнов, что воспринимается как пожелание им материального достатка, здоровья и многочадия. Эти и другие сохранившиеся в нашем народе практики архаического происхождения также отсылают нас к общеславянскому почитанию Земли-Матери. Вообще подобное сакральное отношение к хлебу и злаковым, безусловно, встречается и в других культурах. Это, можно сказать, архетипическое представление, поскольку хлеб - основная и важнейшая еда на столе человека. Для древнего же славянина хлеб и зерно священны ещё и в силу святости земли, их произведшей. Высокий аксиологический статус пшеничного хлеба, а также злаков, используемых для его изготовления, приобрёл в сознании наших предков дополнительное обоснование в связи с евхаристическим контекстом его использования. Всякий «белый» хлеб рассматривался в народной среде как прообраз или даже потенциальный субстрат хлеба евхаристического. Проекцией данной сакрализации становилось особое отношение к столу, который часто воспринимался благочестивыми христианами как подобие алтарного Престола. В 1989 г. автору этих строк доводилось слышать порицание недолжного обращения с обеденным столом из уст жительницы Рязанской области В. Е. Кузнецовой, происходившей из крестьян Курского региона: «Не смей делать так (стучать по столу. - Aвm.) Стол это престол».

В современной российской деревне, связывающей начало нового земледельческого цикла с зимними святками, которые сопровождаются в том числе и колядованием, а также магическими действиями с зерном и хлебом ${ }^{27}$, этим обычаям придают символическое значение. «Несмотря на то, что в настоящее время колядование не является серьёзным магическим обрядом, обрядовое слово в устах младшего поколения не теряет заклинательного характера и актуализируется стремлением привлечь в дом благополучие, довольство, достаток,

26 См., например: Элиаде М. Священное и мирское / пер. с фр., предисл. и коммент. Н. К. Гарбовского. М., 1994. С. 17-19.

27 См.: Сережко Т. А. Народная религиозность в современной крестьянской субкультуре:дисс. на соискание учёной степени кандидата философских наук: 24.00.01. Белгород, 2010. C. 98. 
здоровье» ${ }^{28}$, - свидетельствует Т. А. Сережко, исследовавшая проявления народной религиозности в российских сёлах и деревнях.

Трепетное отношение к земле, являвшейся кормительницей человека, от которой зависели его жизнь и благополучие, нашло выражение в формировании замечательной народной мифопоэтической традиции, выделившей образ Земли «среди всех других природно-космологических образов особой интимностью отношения к нему, редкой полнотой, целостностью и вместе с тем детальностью представлений о нём и... столь же высокой степенью антропоморфизма, персонифицированности и даже одухотворённости, что земля стала Землёй, мифологическим персонажем» ${ }^{29}$.

Определения «мать-сыра земля», «земля-матушка» на слуху у человека русской культуры едва ли не с младенчества. Ребёнок растёт на мифологических образах, заимствованных из русских сказок, где главный герой, прикоснувшись к земле, обретает богатырскую силу или способность менять облик - стать то «серым волком», то «ясным соколом». Без преувеличения, и по сей день к Земле-Матери «стекаются наиболее таинственные и глубокие религиозные чувства» ${ }^{30}$ русского человека. Прилагая к земле упомянутые выше и подобные им ласковые эпитеты, наш народ распространил её сакральность на всё место своего проживания. Отсюда и представления о святости родной земли (Русской земли), о Родине-Матери и, соответственно, о её «священных рубежах», которые необходимо хранить и защищать. Сакральностью, таким образом, наделяется не только земля как материальная субстанция, то есть плодородная почва, производящая растения и питающая животных и людей, но и всё пространство проживания народа - физическое и духовное: будь то страна как территория, как «священная держава» (о чём поётся в современном российском гимне), или же как Святая Русь, высший духовно-нравственный идеал народной жизни.

28 См.: Сережко Т. А. Народная религиозность в современной крестьянской субкультуре:дисс. на соискание учёной степени кандидата философских наук: 24.00.01. Белгород, 2010. C. 100 .

29 Топоров В.Н. К реконструкции балто-славянского мифологического образа Земли-Матери. С. 268.

30 Федотов Г. П. Собрание сочинений в 12 т. Т. 10: Русская религиозность. Часть І. Христианство Киевской Руси. Х-ХІІІ вв. М., 2015. С. 24. 


\section{Выводы}

Сложно не согласиться с заключением авторов «Славянских древностей», справедливо указывавших на то, что «в народной религии, народной морали существовали целые комплексы представлений и действий, оцениваемых такой мерой добра и зла, которая была чужда христианскому мировосприятию в принципе» ${ }^{31}$. Но при этом в народном сознании данные комплексы представлений не только не входили в противоречие с христианским самоопределением людей, но и были органичной частью народной души, «предопределяющей и матрицирующей определённый религиозно-психологический тип и весь его жизненный контекст» ${ }^{32}$.

На первый взгляд, может показаться, что почитание земли, являющееся отголоском древнего культа плодородия, а потому характерное прежде всего для общества с аграрной экономикой, сегодня едва ли выходит за пределы сёл и деревень, сохраняющих патриархальный уклад жизни, хотя даже современные крестьянские (фермерские) хозяйства, испытывают ныне огромное влияние высоких технологий.

Живя в постиндустриальном обществе, определяющую роль в развитии которого продолжают играть города как центры промышленности, производства услуг и получения знаний, мы могли бы ожидать общей деградации (если не полного исчезновения) подобных архаических представлений о земле. Вместе с тем активно развивающееся в России дачное движение, популярность идеи так называемых родовых поместий, пропагандируемой такими неоязыческими(?) сектами, как, например, «Звенящие кедры России», и воспринятой даже на политическом уровне через реализацию государственной программы о бесплатном предоставлении в ряде регионов 1 гектара каждому желающему - всё это свидетельствует о том, что тяга к земле у русского народа не ослабевает и остаётся одной из конституирующих особенностей национального самосознания. Более того, даже люди, родившиеся в городах и проведшие всю свою сознательную жизнь в урбанистической среде, испытывают потребность в общении и «единении» с природой.

Однако при этом следует признать, что сегодня сложилась довольно парадоксальная ситуация, при которой в сознании многих людей такая любовь к природе совершенно неоправданно противопоставляется

31 Толстой Н. И. Грех // Славянские древности. Этнолингвистический словарь. Т. 1. С. 545.

32 Топоров В.Н. К реконструкции балто-славянского мифологического образа Земли-Матери... С. 243. 
христианскому мировоззрению. Видимо, дали о себе знать долгие столетия упорной борьбы Церкви с проявлениями язычества. Но включение «зелёной повестки» в современную просветительскую деятельность Церкви с совершением особого чина молебного пения «о сохранении творения Божия» 33 , с участием в различных экологических проектах и акциях призвано разрешить это историческое недоразумение и преодолеть непонимание людьми истинного отношения христианина к окружающей природе, которая мыслится им как «дом, где человек является не хозяином, а домоправителем, а также храм, где он священник, служащий, впрочем, не природе, а единому Творцу. В основе понимания природы как храма лежит идея теоцентризма: Бог, дающий всему жизнь и дыхание и всё (Деян. 17, 35), является Источником бытия. Поэтому сама жизнь в многоразличных её проявлениях носит священный характер, являясь Божиим даром, попрание которого есть вызов, брошенный не только божественному творению, но и Самому Господу» 34 .

\section{Источники}

Jakobson R. Slavic Mythology // Funk and Wagnall's Standard Dictionary of Folklore, Mythology and Legend. 1972. P. 1025-1028.

Агапкина Т. А. Духов день // Славянские древности. Этнолингвистический словарь: В 5 т./ под общ. ред. Н. И. Толстого. Т. 2: Д-К (Крошки). М., 1999. С. 157-158.

Апокрифы Древней Руси / сост., предисл. М. В. Рождественской. СПб.: Амфора, 2002.

Зализняк А. А. Проблемы славяно-иранских языковых отношений древнейшего периода // Вопросы славянского языкознания. 1962. Вып. 6. С. 28-47.

«Народная Библия»: восточнославянские этиологические легенды / сост. и коммент. О. В. Беловой; отв. ред. В. Я. Петрухин. М.: Индрик, 2004.

Некрылова А. Ф. Русский традиционный календарь на каждый день и для каждого дома. СПб.: Азбука-классика, 2009.

Основы социальной концепции Русской Православной Церкви. М.: Отдел внешних церковных связей, 2008.

Русский народ (Вера и обычаи. Работа и быт. Будни и праздники). Этнографическая энциклопедия в 2 т. / гл. ред., сост. О. А. Платонов. М.: Институт русской цивилизации, 2013.

33 Текст соответствующего чина утверждён решением Священного Синода Русской Православной Церкви 13 июля 2015 г. (журнал № 41). Согласно этому решению, данное молебное пение ежегодно совершается во всех храмах Московского Патриархата в первое воскресенье сентября.

34 Основы социальной концепции Русской Православной Церкви. М., 2008. С. 148-149. 
Смирнов С. И. Исповедь земле // БВ. 1912. Т. 4. № 11. С. 501-537.

Страхов А. Б. Культ хлеба у восточных славян. Опыт этнолингвистического исследования. München: Verlag Otto Sagner, 1991.

Толстой Н. И. Грех // Славянские древности. Этнолингвистический словарь: В 5 т. / под общ. ред. Н. И. Толстого. Т. 1: А-Г. М.: Институт славяноведения РАН - Международные отношения, 1995. С. 544-546.

Трубачёв О. Н. Из славяно-иранских лексических отношений // Этимология. 1965. Материалы и исследования по индоевропейским и другим языкам. М.: Наука, 1967. С. 3-81.

Трубачёв О. Н. Труды по этимологии: слово, история, культура. В 4 т. М.: Языки славянской культуры, 2005. Т. 2.

\section{Литература}

Живов В. М. Грђховодник. К истории слова и понятия // Очерки исторической семантики русского языка раннего Нового времени / под ред. В. М. Живова. М.: Языки славянских культур, 2009. С. 405-430.

Журавлёв А. Ф. Эволюции смыслов. М.: ЯСК, 2016.

Сережко Т. А. Народная религиозность в современной крестьянской субкультуре: дисс. на соискание учёной степени кандидата философских наук: 24.00.01. Белгород, 2010.

Топоров В. Н. К реконструкции балто-славянского мифологического образа Земли-Матери *Zemia \& *Mātē ("Mati) // Балто-славянские исследования 1998-1999. XIV. Сборник научных трудов. М.: Индрик, 2000. С. 239-371.

Топоров В. Н. Об одном архаичном индоевропейском элементе в древнерусской духовной культуре - *svęt // Языки культуры и проблемы переводимости. М.: Наука, 1987. С. $184-252$.

Топоров В. Н. Из славянской языческой терминологии: индоевропейские истоки и тенденции развития // Этимология. 1986-1987 / под ред. Ж. Ж. Варбот, Л. А. Гиндина, Г. А. Климова, В. А. Меркуловой, В. Н. Топорова, О. Н. Трубачева. М.: Наука, 1989. C. 3-50.

Топоров В. Н. Святость и святые в русской духовной культуре: В 2 т. Т. 1. Первый век христианства на Руси. М.: Гнозис; Школа «Языки русской культуры», 1995.

Федотов Г. П. Стихи духовные (Русская народная вера по духовным стихам) / вступ. ст. Н. И. Толстого. М.: Прогресс; Гнозис, 1991.

Федотов Г. П. Собрание сочинений в 12 т. Т. 10: Русская религиозность. Часть І. Христианство Киевской Руси. X-XIII вв. М.: Sam and Sam, 2015.

Элиаде М. Священное и мирское / пер. с фр., предисл. и коммент. Н. К. Гарбовского. М.: МГУ, 1994. 